\title{
MINERALIZATION OF REGENERATED CELLULOSE HYDROGELS INDUCED BY HUMAN BONE MARROW STROMAL CELLS
}

\author{
P. L. Granja, ${ }^{1,2 *}$ B. De Jéso, ${ }^{3}$ R. Bareille, ${ }^{4}$ F. Rouais,${ }^{4}$ C. Baquey ${ }^{4}$ and M. A. Barbosa ${ }^{1,2}$
}

${ }^{1}$ INEB - Instituto de Engenharia Biomédica, Laboratório de Biomateriais, Rua do Campo Alegre, 823 - 4150-180

Porto, Portugal ${ }^{2}$ Universidade do Porto, Faculdade de Engenharia, Dept. Engenharia Metalúrgica e de Materiais

${ }^{3}$ Institut du Pin, Laboratoire de Chimie des Substances Végétales (LCSV), Université Bordeaux 1, Cours de la Libération - 33405 Talence Cedex, France ${ }^{4}$ INSERM U.443, Université Bordeaux 2, 146 R. Léo Saignat, Bâtiment 4a - 33076 Bordeaux, France

\begin{abstract}
The proliferation of cultured human bone marrow stromal cells (HBMSC) on regenerated cellulose hydrogels was assessed. Regenerated cellulose hydrogels showed good rates of HBMSC proliferation, the cells exhibiting a flattened morphology, and after 22 days in culture, the cells had homogeneously colonized the surface of the materials. Moreover, since the early days in culture, between the surface of the materials and attached cells a continuous granulated hydroxyapatite layer was formed. It has been previously demonstrated in vitro, but without cells, that these materials did not mineralize. Hence, it seems that HBMSC promoted the mineralization of the surface.
\end{abstract}

Key Words: Regenerated cellulose hydrogels, human bone marrow stromal cells, cell proliferation, mineralization, calcium phosphates, hydroxyapatite.

*Address for correspondence:

P.L. Granja

INEB - Instituto de Engenharia Biomédica

Laboratório de Biomateriais

Rua do Campo Alegre, 823

4150-180 Porto, Portugal

Telephone Number: 351-226074900

FAX Number: 351-226094567

E-mail: pgranja@ineb.up.pt.

\section{Introduction}

The understanding of the interaction between bone cells and polymer surfaces is of paramount importance in the development of bone substitute biomaterials. A close apposition between bone and biomaterial, or osseointegration, is considered to be one of the major factors leading to a successful skeletal implantation (Hosseini et al., 2000; Albrektsson, 1998; Friedman et al., 1993). It is widely accepted that the attachment of osteoblast-like cells to material surfaces may lead to improved bone integration and hence longer-term stability of load-bearing implants (Hosseini et al., 2000; Albrektsson, 1998; Friedman et al., 1993; Puleo and Nanci, 1999). Recent advances from tissue-engineered orthopaedic biomaterials confirm that adequate substrates for bone cell growth and differentiation constitute adequate scaffolds to prepare functional hybrid biomaterial/new bone 3D structures (Yaszemski et al., 1996; von Recum et al., 1999; Patrick et al., 1998; Burgess and Hollinger, 1998).

Osteoblasts are anchorage-dependent cells and their attachment to synthetic surfaces is a complex process involving cell attachment and spreading, focal adhesion formation, and extracellular matrix formation and reorganization (Lamba et al., 1998). Materials surface properties influence the composition of the adsorbed protein compounds, which in turn regulates how cells respond to the material (Lamba et al., 1998; Horbett, 2004; McFarland et al., 1999; Healy et al., 1996). Understanding the relationship between material surface properties, adsorbed molecules and cellular responses is essential to designing optimal material surfaces for implantation and tissue engineering.

Cellulose is the world's most abundant natural, renewable and biodegradable polymer. Similarly to other polysaccharides, cellulose has a long background in medical applications, essentially due to its lack of toxicity (monomer residues are part of metabolites found in the human body), water solubility or high swelling ability, and stability to temperature and $\mathrm{pH}$ variations (Hon, 1996; Franz, 1986). The biocompatibility of unmodified and derivatised cellulose is well documented (Hon, 1996; Franz, 1986; Martson et al., 1998; Chauveaux et al., 1990; Miyamoto et al., 1989; Ikada, 1989). Oxidized cellulose has been used for decades as a wound dressing and for osseous regeneration (Dias et al., 2003; Uysal et al., 2003; Galgut, 1990; Skoog, 1967; Degenshein et al., 1963), and regenerated cellulose sponges have shown to promote 
bone regeneration (Martson et al., 1998, 1999). Regenerated cellulose hydrogels (cellulose regenerated by the viscose process, $\mathrm{CRV}^{\circledR}$ ) have been investigated as implantable materials in orthopaedic surgery as an attachment material for the femoral component in hip prostheses, in place of the acrylic cement (Gross et al., 1992; Chauveaux et al., 1990; Poustis et al., 1994; Pommier et al., 1990). It was envisaged to take advantage not only of its good matching with mechanical properties of cortical bone, but also of its hydroexpansivity, therefore allowing a satisfactory primary fixation to hard tissue. The biocompatibility and osteoconductive properties of these regenerated cellulose hydrogels have been demonstrated in vivo (Gross et al., 1992; Chauveaux et al., 1990; Pommier et al., 1990).

In the context of a program aimed at investigating the biological behaviour of modified cellulose, the in vitro biocompatibility of regenerated cellulose hydrogels was evaluated with cultured HBMSC, in terms of cytotoxicity and cell attachment. It was demonstrated that these materials are cytocompatible and promote attachment of HBMSC to a good extent (Granja et al., submitted).

In the present work, the mineralization accompanying the proliferation of HBMSC on regenerated cellulose hydrogels was investigated.

\section{Materials and Methods}

Regenerated cellulose hydrogels (cellulose regenerated by the viscose process, $\mathrm{CRV}^{\circledR}$ ) were a generous gift from Hexabio (Bordeaux, France), and were obtained by a previously described method (Pommier et al., 1990). CRV discs $(10 \times 2 \mathrm{~mm})$ used in cell cultures were machined from blocks dried in air at room temperature. The discs were dialyzed against distilled water for 24 hours before use, in order to remove contamination resulting from machining. All chemicals were of research grade purity, and used without further purification.

Sterilization. After packing, samples were $\gamma$-irradiated for $8 \mathrm{~h}$ and $30 \mathrm{~min}$ at room temperature in the absence of oxygen, in a CIS Bio-Industries (Gif sur Yvette, France) equipment, model IBL 337, loaded with 13000 curies of ${ }^{137} \mathrm{Cs}$, in order to absorb a total dose equal to $25 \mathrm{kGy}$.

Cell cultures. Osteoblast-like cells were isolated from human bone marrow stromal cells (HBMSC), according to Vilamitjana-Amédée et al. (1993), with some modifications. Briefly, human bone marrow was obtained by aspiration from the iliac crest of healthy donors (aged 20-50 years) undergoing hip prosthesis surgery. Cells were pooled and separated into a single suspension by sequentially passing the suspension through syringes fitted with 16, 18 or 21 gauge needles. After centrifugation for $15 \mathrm{~min}$ at $800 \mathrm{~g}$, the pellet was resuspended in Iscove Modified Dulbecco's Medium (IMDM, from Gibco, InVitrogen, Carlsbad, CA, U.S.A.) supplemented with 10\% $(\mathrm{v} / \mathrm{v})$ fetal calf serum (FCS, from Gibco) and $10^{-8} \mathrm{M}$ dexamethasone (Sigma, St. Louis, MO, U.S.A.). Cells were then plated into $75 \mathrm{~cm}^{2}$ cell culture flasks (Nalge Nunc, Rochester, NY, U.S.A.), at a density of $5 \times 10^{5}$ cells $/ \mathrm{cm}^{2}$, and incubated in a humidified atmosphere of $95 \%$ air $5 \%$
$\mathrm{CO}_{2}$ at $37^{\circ} \mathrm{C}$. Three days later, the medium was removed, replaced 2 times with the complete medium supplemented with $10^{-8} \mathrm{M}$ dexamethasone, and then every 3 days with IMDM containing $10 \%$ FCS (v/v). Subculturing was performed using $0.2 \%(\mathrm{w} / \mathrm{v})$ trypsin and $5 \mathrm{mM}$ ethylenediaminetetraacetic acid (EDTA). Cell differentiation was followed by the measurement of alkaline phosphatase activity and osteocalcin synthesis, as described previously (Vilamitjana-Amédée et al., 1993). All cell assays described were performed using at least 6 replicates for every condition tested.

Cell proliferation. Cell proliferation assays were performed as described by Mosmann (1983). Cell attachment and proliferation on tissue culture polystyrene (TCPS) of plastic culture dishes was used as the positive control. In order to prevent cell attachment to plastic dishes, an agarose layer $(2 \%(\mathrm{v} / \mathrm{v})$ in $0.1 \mathrm{M}$ phosphate buffered saline (PBS at pH 7.4) was poured into 24-well plates, and constituted the negative control (Amédée et al., 1994). Cellulose discs were then placed onto this agarose layer and incubated overnight, at $37^{\circ} \mathrm{C}$, in IMDM. Thereafter, discs were seeded with a density of 5000 cells per $\mathrm{cm}^{2}$ in $10 \%(\mathrm{v} / \mathrm{v}) \mathrm{FCS}$ in IMDM. Cultures were incubated at $37^{\circ} \mathrm{C}$ in a humidified atmosphere. The culture medium was replenished every 3 days. Cell growth was quantified at $1,3,8,15$ and 22 days, by measuring the cell metabolic activity by the MTT assay (based on the observation that a mitochondrial enzyme of viable cells has the ability to metabolize a water-soluble tetrazolium dye 3-(4,5dimethylthiazol-2-yl)-2,5-diphenyl tetrazolium bromide into an insoluble formazan salt). Briefly, $3 \mathrm{~h}$ after incubation of MTT at $37^{\circ} \mathrm{C}$, the MTT solution was removed, the insoluble formazan crystals formed were dissolved in dimethylsulfoxide and $100 \mu \mathrm{L}$ were aspirated and then poured into another 96 -well plate, for absorbance measurement at $540 \mathrm{~nm}$. The intensity of the staining obtained is directly proportional to cell proliferation (AFNOR, 1994; ISO, 1992). Agarose was used as the negative control. Results are expressed as percentage of cell growth on TCPS, which is defined as $100 \%$.

Light microscopy. Observations of unfixed cells were carried out on cell culture plates, using an Olympus IM inverted microscope.

Cell morphology and surface characterization. Scanning electron microscopy (SEM) was carried out in order to study cell morphology on the culture discs. Samples were fixed by $15 \mathrm{~min}$ immersion in a $2 \%(\mathrm{v} / \mathrm{v})$ glutaraldehyde in $0.15 \mathrm{M}$ cacodylate buffer $(\mathrm{pH} 7.3)$. Samples were washed with $0.15 \mathrm{M}$ cacodylate buffer for $10 \mathrm{~min}$, then dehydrated by successive immersions in ethanol solutions (from 25 to $100 \%$ ), then finally dried by the $\mathrm{CO}_{2}$ critical point technique, and Au-sputtered before observation. SEM analyses were carried out at 15 and 20 $\mathrm{keV}$ for $60 \mathrm{~s}$, using a Hitachi (Tokyo, Japan) S-2500 scanning electron microscope. Mineralized areas were analysed using an energy dispersive $\mathrm{x}$-ray analysis system (Noran Voyager, Thermo Electron Corp., Philadelphia. PA, USA).

The mineralized surfaces of the samples were further characterized by Attenuated Total Reflectance-Fourier Transform Infrared (ATR-FTIR) spectroscopy with a 
Perkin Elmer (Wellesley, MA, U.S.A.) 2000 FT-IR Spectrometer, using the Split Pea accessory (Harrick Scientific Corporation, Pleasantville, NY, U.S.A), equipped with a silicon hemispherical crystal. All samples were run at a spectral resolution of $4 \mathrm{~cm}^{-1}$.

Statistical verification of results. The results were statistically analyzed by one-way ANOVA using SPSS (Chicago, IL, U.S.A.) 10.0.01. The level of significance was set at $\mathrm{p}<0.05$.

\section{Results}

As can be observed in Fig. 1, HBMSC proliferate at a good rate over regenerated cellulose hydrogel discs, achieving proliferation rates of $72.9 \% \pm 13.7$ after 15 days in culture and $76.7 \% \pm 24.7$, after 22 days, as expressed as percentage of the proliferation observed in the TCPS controls. Differences found to cell proliferation over agarose at these time points were statistically significant.

SEM observations (Fig. 2) clearly demonstrate these findings. Cells adapted very closely to the surface and

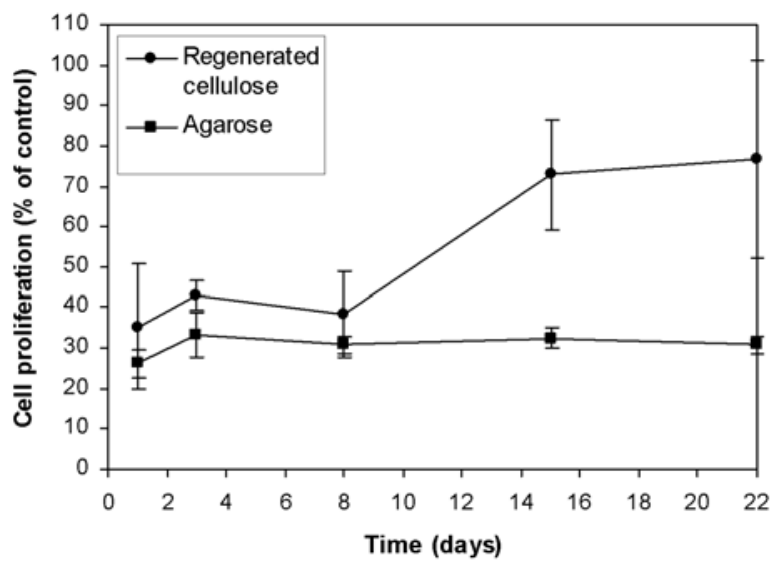

Figure 1. Proliferation rates of human bone marrow stromal cells on regenerated cellulose hydrogels, compared to the negative controls over agarose. Data are expressed as $\%$ of proliferation of the positive controls on tissue culture polystyrene.

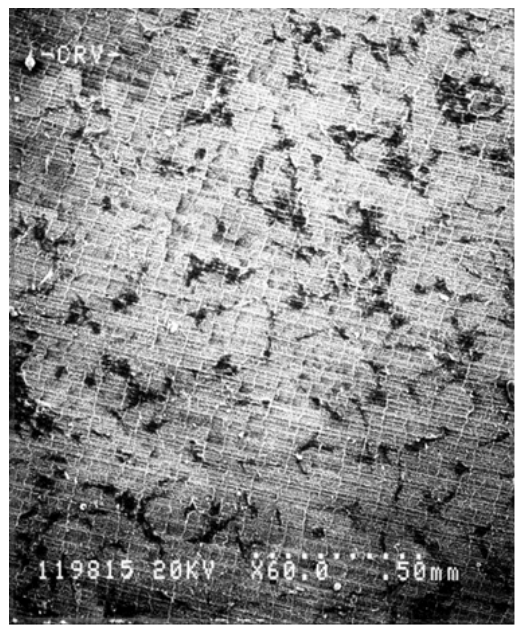

a

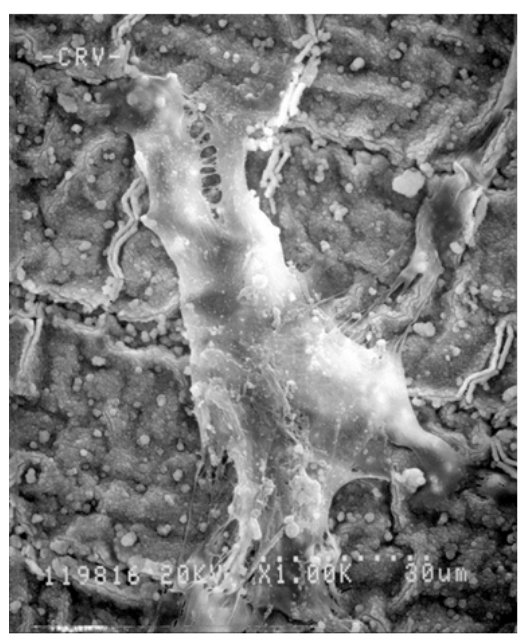

d

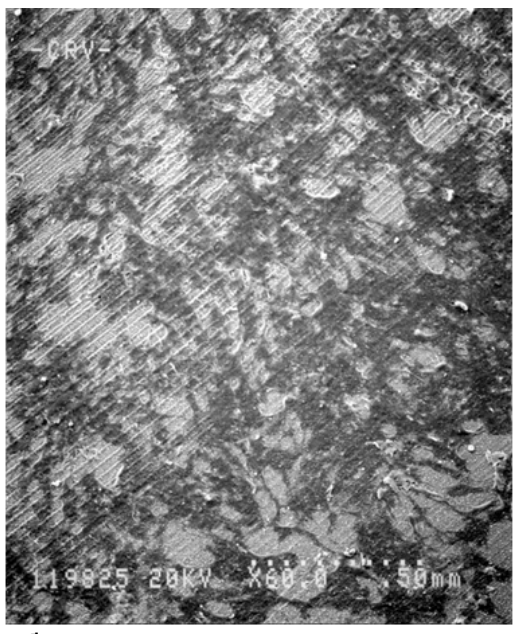

b

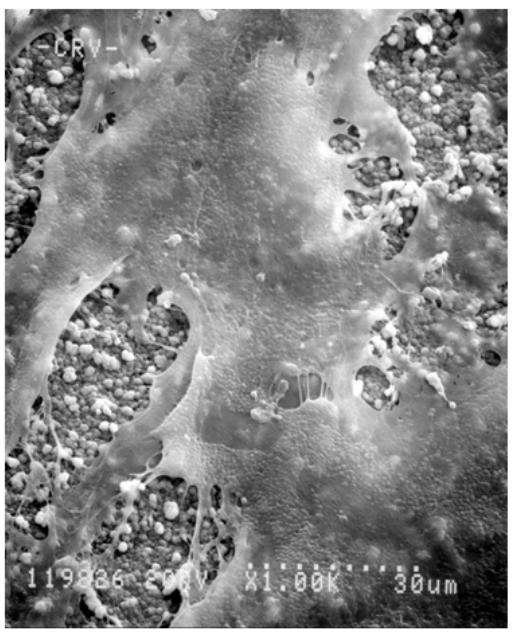

e

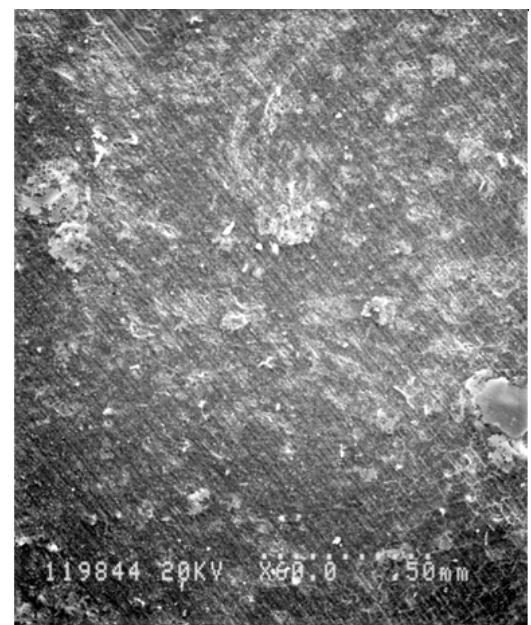

C

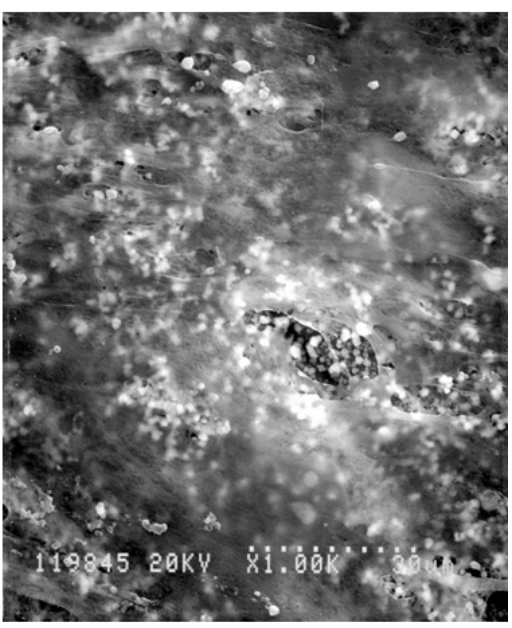

f

Figure 2. SEM micrographs of the proliferation and attachment of human bone marrow stromal cells on regenerated cellulose hydrogels after: a) and d) 3 days; b) and e) 15 days; and c) and f) 22 days. At lower magnification, in Figs. $2 \mathrm{a}, 2 \mathrm{~b}$ and $2 \mathrm{c}$, the cells constitute the darker areas. In Figs. $2 \mathrm{c}$ and $2 \mathrm{f}$ it can be seen that the surface is almost totally covered by the cells. 

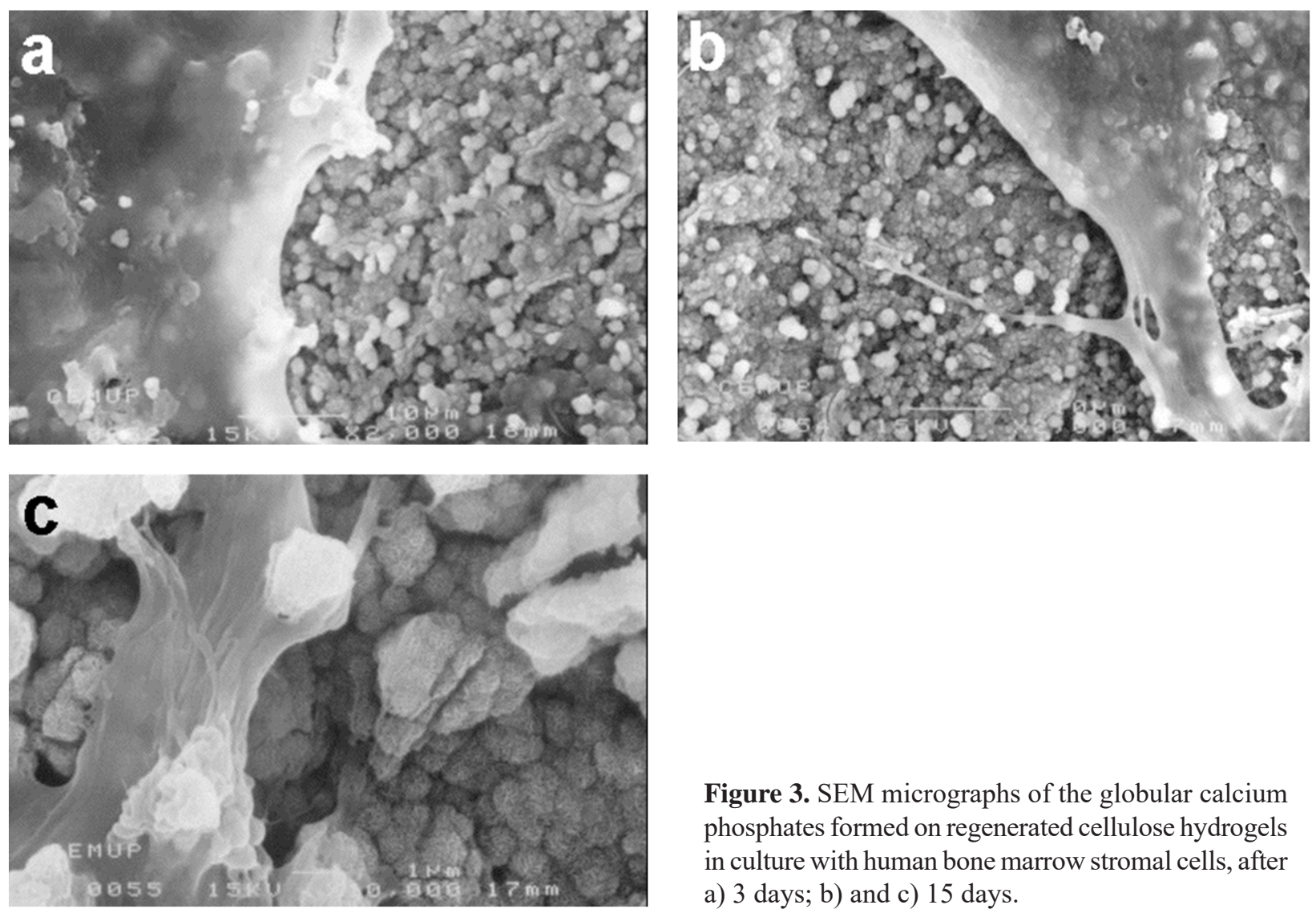

Figure 3. SEM micrographs of the globular calcium phosphates formed on regenerated cellulose hydrogels in culture with human bone marrow stromal cells, after a) 3 days; b) and c) 15 days.
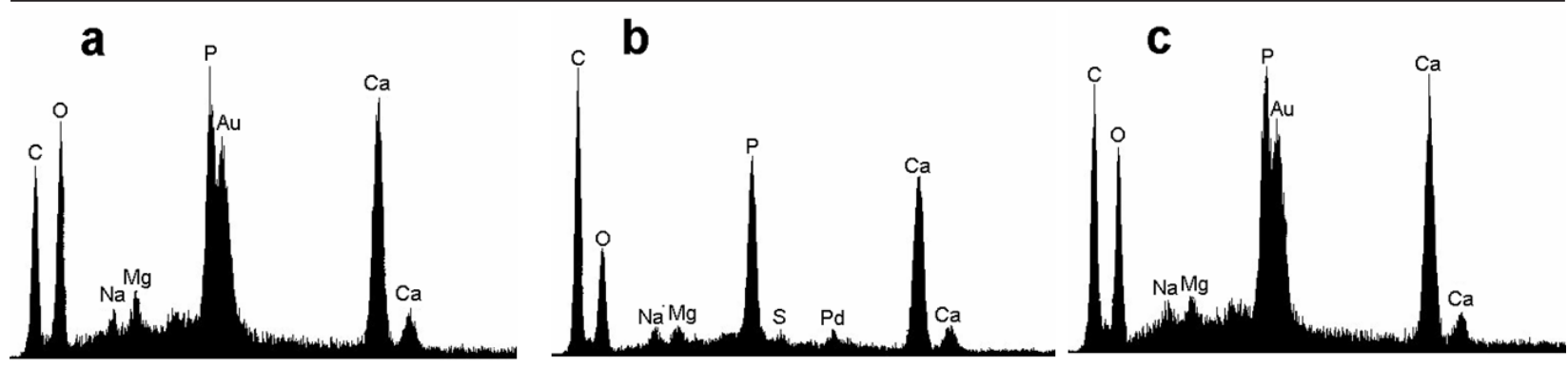

Figure 4. EDS microanalysis spectra of the calcium phosphates formed on regenerated cellulose hydrogels in culture with human bone marrow stromal cells, after a) 3 days, b) 15 days and c) 22 days.

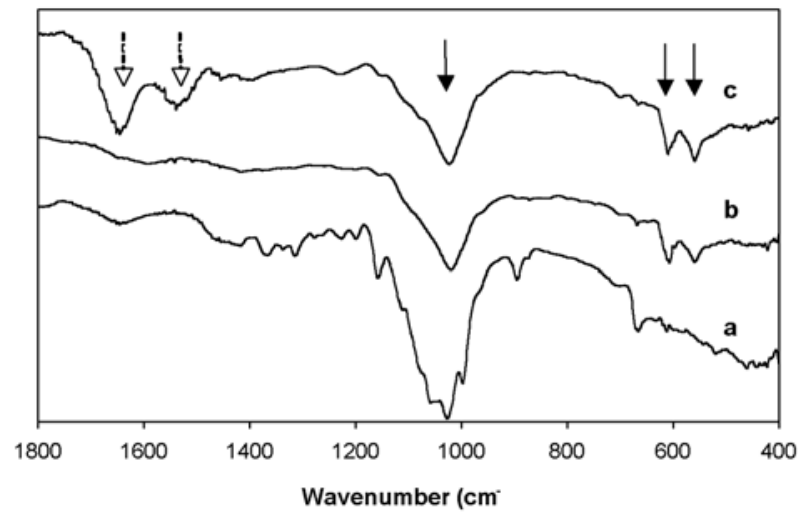

Figure 5. ATR-FTIR spectra of samples analysed, in the $400-1800 \mathrm{~cm}^{-1}$ window, showing the formation of an hydroxyapatite layer with its characteristic $v_{3}$ (at about $1016 \mathrm{~cm}^{-1}$ ) and $\mathrm{v}_{4} \mathrm{PO}_{4}$ (at 557 and $605 \mathrm{~cm}^{-1}$ ) vibrations (solid arrows): a) regenerated cellulose hydrogel; regenerated cellulose in culture with human bone marrow stromal cells after: b) 3 days, and c) 22 days. exhibited a flattened morphology. Contact between adjacent cells was also observed in every case. The amount of cells on the surfaces increased with time (Figs. 2a to $2 \mathrm{f}$ ), until the substrate could hardly be observed, after 22 days, since it was almost completely covered by cells (Figs. $2 \mathrm{c}$ and $2 \mathrm{f}$ ).

Figs. $2 \mathrm{~d}$ through $2 \mathrm{f}$ seem to indicate that the surfaces contacted by cells are changing in the course of time from the original structure of regenerated cellulose. At further magnifications (Fig. 3), a homogeneous layer featuring globular structures, which was later identified as calcium phosphates and hydroxyapatite, could be distinguished between the cell layer and the cellulose surface. Cells are observed to attach very closely to those globular structures, following their topography.

$\mathrm{The} \mathrm{Ca} / \mathrm{P}$ ratio of the calcium phosphate formed, as analysed by EDS microanalysis (Fig. 4), was found to decrease from about 1.88, after 3 days in culture, to about 1.59 , after 22 days. 
ATR-FTIR analyses of the calcium phosphates formed (Fig. 5) showed that they are apatitic since, in addition to the $\mathrm{OH}$ bands, the characteristic $\mathrm{v}_{3}$ (at ca. $1016 \mathrm{~cm}^{-1}$ ) and $\mathrm{v}_{4} \mathrm{PO}_{4}$ (at 557 and $605 \mathrm{~cm}^{-1}$ ) vibrations were observed, which are typical of apatitic minerals. Furthermore, after 22 days in culture (Fig. 5c), where cells covered the material surface, two additional peaks, centered at 1539 $\mathrm{cm}^{-1}$ and $1643 \mathrm{~cm}^{-1}$ (dashed arrows) were observed.

\section{Discussion}

In previous studies, contact angle measurements confirmed the moderate hydrophilicity of regenerated cellulose hydrogels (Granja et al., 2001a). It was demonstrated that HBMSC attached at a good extent on regenerated cellulose hydrogels and that these materials are cytocompatible (Granja et al., submitted). Their ability to promote HBMSC proliferation was also quantified and results obtained showed that they are adequate substrates for HBMSC proliferation and growth. However, HBMSC morphology on these substrates has not been investigated.

In the present investigation, proliferation of HBMSC on regenerated cellulose hydrogels was observed to a relatively high extent. Changes in proliferation were low in the first 8 days and then increased gradually towards the 15th day. HBMSC cultured on regenerated cellulose hydrogels attached very closely, exhibited a flattened morphology, and contact between adjacent cells was observed, which is typical of well-attached and grown cells (Puleo and Bizios, 1992; Shelton et al., 1988). These findings indicate that regenerated cellulose hydrogels not only allow a good attachment of HBMSC with spreading and acceptable proliferation of the cells. After 22 days in culture, the materials surface was almost completely colonized by well-attached HBMSC.

The good HBMSC attachment and proliferation found can be attributed to the peculiar properties of regenerated cellulose hydrogels for biomedical applications, namely their high purity and high water uptake or swelling, causing less physical damage to cells (Dumitriu and Dumitriu, 1996; Smetana, 1993), associated with their moderate hydrophilicity. In the literature, the role of hydrophilicity in cell adhesion has been widely discussed and, despite the difficulty in isolating this property from the other influencing ones, the general conclusion seems to be that moderate hydrophilicity favours cell adhesion, and extreme values inhibit this phenomenon (Smetana, 1993; Lee et al., 1997; Choee et al., 2004; Webb et al., 1998). A certain amount of free hydroxyl groups on these hydrogels is also expected to favour cell adhesion. It was previously reported by Curtis et al. (1986) that moderate hydroxylation enhances cell adhesion and extreme values prevent it.

Analysis of the ATR-FTIR spectra showed peaks centered at $1539 \mathrm{~cm}^{-1}$ and $1643 \mathrm{~cm}^{-1}$, on surfaces after 22 days in cell culture, which can be attributed to amino acids from cellular structures, since those surfaces were nearly totally covered by cells.

After contact with cells, the surface of regenerated cellulose hydrogels was significantly changed, as depicted in Figs. 2 and 3. SEM observations at high magnifications, along with EDS microanalysis and ATR-FTIR spectroscopy, showed that a hydroxyapatite layer was formed between the materials surface and attached HBMSC. In addition to the $\mathrm{OH}$ bands, the $v_{3}$ and $v_{4} \mathrm{PO}_{4}$ vibrations were assigned, which are typical of apatitic minerals (Bohic et al., 1998; Dasarathy et al., 1993). In previous studies, the mineralization of regenerated cellulose hydrogels was investigated and it was shown that these materials did not mineralise in Simulated Body Fluid (SBF), except when they were previously treated with calcium chloride (Granja et al., 2001b; Granja et al., 2001c). In the present study, untreated cellulose materials mineralised in HBMSC culture, which can only be attributed to the action of cells themselves, and/or to the culture medium used. In fact, it can be deduced that HBMSC proliferated to a higher extent only on the apatitic mineral layer formed and not on the cellulose surface. The mechanism governing mineralization on regenerated cellulose hydrogels in HBMSC culture must be further investigated in order to better understand and to promote this same behaviour on skeletal implant biomaterials.

At present, only a few available polymeric biomaterials have shown the capability of constituting adequate substrates for bone cell attachment, growth and differentiation in such a way that they allow cells to produce mineralised tissue. Some cues can be summarized from the present work, namely: an hydrogel structure, availability of free $\mathrm{OH}$ groups and moderate hydrophilicity. The emerging field of tissue engineering, and more specifically for orthopaedic applications, requires materials that promote the proliferation and growth of viable bone cells expressing their phenotype, in order to promote the formation of new bone on the surface of the materials, or in a 3D porous structure (von Recum et al., 1999; Burgess and Hollinger, 1998). At present, among the most promising substrates for tissue engineered bone tissue are porous biodegradable scaffolds made from polymers belonging to the family of the poly( $\alpha$-hydroxy) acids, namely poly(lactide), poly(glycolide), and their copolymers, mainly due to their good biocompatibility, good interaction with bone cells, adjustable biodegradation in the human body into metabolic residues, commercial availability, among other adequate properties (von Recum et al., 1999; Ishaug et al., 1997). However, on these materials no direct bone contacts have been observed, and some complications were reported in vivo, namely inflammatory reactions at the site of implantation, or even tissue necrosis, which were attributed to the release of lactic acid and consequent local tissue acidification (von Recum et al., 1999; Bergsma et al., 1995; Vert et al., 1994). Cellulose cannot be considered as a biodegradable alternative since it is not digestible in the human organism (Miyamoto et al., 1989; Hayashi, 1994). Nevertheless, the interesting properties revealed in the present work, associated with its adequate mechanical properties, lack of toxicity and long experience in medical applications, make it an interesting alternative, as a porous material, for many applications where, at present, no adequate degradation rates seem to match specific requirements, as 
is the case of orthopaedic applications, where mechanical properties constitute a major requirement. Furthermore, it has been reported that several chemical modifications can make it biodegradable, if considerable changes in the higher order structure of cellulose are performed (Miyamoto et al., 1989; Hayashi, 1994). In addition, several other biodegradable polysaccharides have promising properties as biomaterials, although relatively little attention has been paid to their application e.g., in the orthopaedic field.

\section{Conclusions}

Regenerated cellulose hydrogels are biocompatible and showed good rates of HBMSC proliferation, with cells exhibiting a flattened morphology on materials surface. After 22 days in culture, cells homogeneously colonized the materials surface. Moreover, between the materials surface and attached cells, a granulated hydroxyapatite layer was formed homogeneously. In previous studies, using simulated body fluid without cells, mineralization did not occur. Hence, it seems that either HBMSC or the culture medium alone were responsible for promoting the mineralization of the surface which also seemed the prerequisite for proliferation.

\section{Acknowledgements}

The authors would like to express their gratitude to JeanYves Elie (Pôle Aquitaine Génie Biologique Médical, France) and Michel Harribey (Hexabio, France) for the $\mathrm{CRV}^{\circledR}$ samples. Pedro L. Granja is grateful to the Portuguese Foundation for Science and Technology (FCT) for awarding him a scholarship under the programme PRAXIS XXI. The authors also acknowledge the support given by Pôle Aquitaine GBM (Bordeaux, France) and Project PRAXIS 2/2.1/SAU/1393/95, from FCT.

\section{References}

AFNOR-NF EN 30993-5 (1994) Evaluation biologique des dispositifs médicaux. Partie 5: Essais concernant la cytotoxicité: Méthodes in vitro. (Biological evaluation of medical devices. Part 5: Cytotoxicity assays: In vitro methods). Association Française de Normalization, SaintDenis la Plaine, France (www.afnor.fr).

Albrektsson T (1998) Hard tissue response. In: Handbook of Biomaterial Properties. Black J, Hastings G (eds). Chapman \& Hall, London, pp. 500-512.

Amédée J, Bareille R, Jeandot R, Bordenave L, Remy M, Rouais F, Baquey C (1994) Evaluation of cell colonization on biomaterials: preventing cell attachment to plastic containers. Biomaterials 15:1029-31.

Bergsma JE, de Bruijn WC, Rozema FR, Bos RRM, Boering $G$ (1995) Late degradation tissue response to poly(L-lactide) bone plates and screws. Biomaterials 16: 25-31.
Bohic S, Heymann D, Pouezat JA, Gauthier O, Daculsi G (1998) Transmission FT-IR microspectroscopy of mineral phases in calcified tissues. Sciences de la vie 321: 865-876.

Burgess EA, Hollinger JO (1998) Options for engineering bone. In: Frontiers in Tissue Engineering. Patrick Jr CW, Mikos AG, McIntire LV (eds). Elsevier Science, Oxford, pp. 383-399.

Chauveaux D, Barbie C, Barthe X, Baquey C, Poustis J (1990) Biological behaviour of cellulosic materials after bone implantation: Preliminary results. Clin Mater 5: 251258.

Choee JH, Lee SJ, Lee YM, Rhee JM, Lee HB, Khang G (2004) Proliferation rate of fibroblast cells on polyethylene surfaces with wettability gradient. J Appl Polym Sci 92: 599-606.

Curtis ASG, Forrester JV, Clark P (1986) Substrate hydroxylation and cell adhesion. J Cell Sci 86: 9-24.

Dasarathy H, Riley C, Coble HD (1993) Analysis of apatite deposits on substrates. J Biomed Mater Res 27: 477-482.

Degenshein GA, Hurwitz A, Ribacoff S (1963) Experience with regenerated oxidized cellulose. NY State J Med 63: 2639-2643.

Dias GJ, Peplow PV, Teixeira F (2003) Osseous regeneration in the presence of oxidized cellulose and collagen. J Mater Sci Mater Med 14: 739-745.

Dumitriu S, Dumitriu M (1996) Hydrogels as support for drug delivery systems. In: Polysaccharides in Medicinal Applications. Dumitriu S (ed.). Marcel Dekker, New York, pp. 705-764.

Franz G (1986) Polysaccharides in pharmacy. Adv Polym Sci 76: 1-30.

Friedman RJ, Black J, Galante JO, Jacobs JJ, Skinner HB (1993) Current concepts in orthopaedic biomaterials and implant fixation. J Bone Joint Surg 75-A: 1086-1109.

Galgut PN (1990) Oxidized cellulose mesh. I. Biodegradable membrane in periodontal surgery. Biomaterials 11: 561-564.

Granja PL, Pouységu L, Deffieux D, Daudé G, De Jéso B, Labrugère C, Baquey C, Barbosa MA (2001a) Cellulose phosphates as biomaterials. Surface chemical modification of regenerated cellulose hydrogels. J Appl Polym Sci 82: 3354-3365.

Granja PL, Pouységu L, De Jéso B, Rouais F, Baquey C, Barbosa MA (2001b) Cellulose phosphates as biomaterials. Mineralization of chemically modified regenerated cellulose hydrogels. J Mater Sci 36: 21632172.

Granja PL, Ribeiro CC, De Jéso B, Baquey C, Barbosa MA (2001c) Mineralization of regenerated cellulose hydrogels. J Mater Sci: Mater Med 12: 785-791.

Hayashi T (1994) Biodegradable polymers for biomedical uses. Prog Polym Sci 19: 663-702.

Healy KE, Thomas CH, Rezania A, Kim JE, McKeown PJ, Lom B, Hockberger PE (1996) Kinetics of bone cell organization and mineralization on materials with patterned surface chemistry. Biomaterials 17: 195-208.

Hon DN-S (1996) Cellulose and its derivatives: Structures, reactions, and medical uses. In: Polysaccharides 
in Medicinal Applications. Dumitriu D (ed.). Marcel Dekker, New York, pp. 87-105.

Horbett TA (2004) The role of adsorbed proteins in tissue response to biomaterials. In: Biomaterials Science: An Introduction to Materials in Medicine, $2^{\text {nd }} E d$. Ratner BD, Hoffman AS, Schoen FJ, Lemons JE (eds.). ElsevierAcademic Press, San Diego, pp. 237-246.

Hosseini MM, Sodek J, Franke R-P, Davies JE (2000) The structure and composition of the bone-implant interface. In: Bone Engineering. Davies JE (ed.). em squared inc., Toronto, pp. 295-304.

Ikada Y (1989) Biomedical applications of cellulose membranes. In: Cellulose: Structural and Functional Aspects. Kennedy JF, Phillips GO, Williams PA(eds.). Ellis Horwood, Chichester, pp. 447-455.

Ishaug SL, Crane GM, Miller MJ, Yasko AW, Yaszemski MJ, Mikos AG (1997) Bone formation by threedimensional stromal osteoblast culture in biodegradable polymer scaffolds. J Biomed Mater Res 36: 17-28.

ISO 10993-5 (1992) Biological evaluation of medical devices. Test for cytotoxicity: In vitro methods. International Organization for Standardization, Geneva, Switzerland (www.iso.org).

Lamba NMK, Baumgartner JA, Cooper SL (1998) Cell-synthetic surface interactions. In: Frontiers in Tissue Engineering. Patrick Jr CW, Mikos AG, McIntire LV (eds). Elsevier Science, Oxford, pp. 121-137.

Lee JH, Lee JW, Khang G, Lee HB (1997) Interaction of cells on chargeable functional group gradient surfaces. Biomaterials 18: 351-358.

Martson M, Viljanto J, Hurme T, Saukko P (1998) Biocompatibility of cellulose sponge with bone. Eur Surg Res 30: 426-432.

Martson M, Viljanto J, Hurme T, Laippala P, Saukko P (1999) Is cellulose sponge degradable or stable as implantation materials? An in vivo subcutaneous study in the rat. Biomaterials 20: 1899-1995.

McFarland CD, Mayer S, Scotchford C, Dalton BA, Steele JG, Downes S (1999) Attachment of cultured human bone cells to novel polymers. J Biomed Mater Res 44: 111.

Miyamoto T, Takahashi S, Ito H, Inagaki H, Noishiki Y (1989) Tissue biocompatibility of cellulose and its derivatives. J Biomed Mater Res 23: 125-133.

Mosmann T (1983) Rapid colorimetric assay for cellular growth and survival: application to proliferation and cytotoxicity assays. J Immunol Meth 65: 55-63.

Patrick Jr CW, Mikos AG, McIntire LV (1998) Prospectus of tissue engineering. In: Frontiers in Tissue Engineering. Patrick Jr CW, Mikos AG, McIntire LV (eds). Elsevier Science, Oxford, pp. 3-11.

Pommier JC, Poustis J, Baquey C, Chauveaux D (1990) Biocompatible, hydrophilic material. Method of manufacture and uses of same (Fr Pat 8610331, 1986; Eur Pat 0256906 A1, 1987) US Pat 4904258.

Poustis J, Baquey C, Chauveaux D (1994) Mechanical properties of cellulose in orthopaedic devices and related environments. Clin Mater 16: 119-124.

Puleo DA, Bizios R (1992) Formation of focal contacts by osteoblasts cultured on orthopedic biomaterials. J
Biomed Mater Res 26: 291-301.

Puleo DA, Nanci A (1999) Understanding and controlling the bone-implant interface. Biomaterials 20: 2311-2321.

Shelton RM, Rasmussen AC, Davies JE (1988) Protein adsorption at the interface between charged polymer substrata and migrating osteoblasts. Biomaterials 9: 2429.

Skoog T (1967) The use of periosteum and surgicel ${ }^{\circledR}$ for bone restoration in congenital clefts of the maxilla. Scand J Plast Reconstr Surg 1: 113-130.

Smetana K Jr (1993) Cell biology of hydrogels, Biomaterials 14: 1046-1050.

Uysal A, Ozbek S, Ozcan M (2003) Comparison of the biological activities of high-density porous polyethylene implants and oxidized regenerated cellulosewrapped diced cartilage grafts. Plast Reconstr Surg 112: 540-546.

Vert M, Mauduit J, Li S (1994) Biodegradation of PLA/ GA polymers: increasing complexity. Biomaterials 15: 1209-1213.

Vilamitjana-Amédée J, Bareille R, Rouais F, Caplan AI, Harmand MF (1993) Human bone marrow stromal cells express an osteoblastic phenotype in culture. In Vitro Cell Dev Biol 29A: 699-707.

von Recum HA, Yaszemski MJ, Mikos AG (1999) Tissue engineering concepts. In: Handbook of Biomaterials Evaluation: Scientific, Technical and Clinical Testing of Implant Materials, 2nd Ed. von Recum AF (ed.), Edwards Brothers, Ann Arbor, pp. 385-409.

Webb K, Hlady V, Tresco PA (1998) Relative importance of surface wettability and charged functional groups on NIH 2T3 fibroblast attachment, spreading and cytoskeletal organization. J Biomed Mater Res 41: 422430.

Yaszemski MJ, Payne RG, Hayes WC, Langer R, Mikos AG (1996) Evolution of bone transplantation: molecular, cellular and tissue strategies to engineer human bone. Biomaterials 17: 175-185.

\section{Discussion with Reviewers}

Reviewer I: Does the culture medium contain betaglycerophosphate or ascorbic acid, and if not, have these investigators performed other experiments with the medium containing beta-glycerophosphate and ascorbic acid, and can compare the results?

Authors: The culture medium in the present experiment was only supplemented with dexamethasone. No, we have not performed such experiments, thus this comparison was out of the scope of the present experiment.

Reviewer I: Are regenerated cellulose hydrogels biologically safe?

Authors: Regenerated cellulose is biologically safe, similarly to several cellulose derivatives that have found biomedical applications. Cellulose membranes for haemodialysis are among the most widely used polymers in therapy. In particular, several other studies have 
confirmed the biological safety of regenerated cellulose, as indicated in the introduction.

Reviewer I: Is regenerated cellulose hydrogel truly biodegradable in human body?

Authors: Cellulose is usually not degraded in the body, since humans do not possess adequate enzymes to do it. However, functionalized cellulose can be rendered biodegradable through changes in its higher order structure. Furthermore, as indicated in the introduction, oxidized regenerated cellulose has been claimed to be slowly

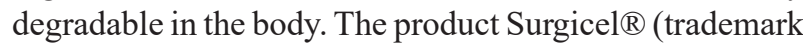
from Johnson \& Johnson) is widely used as a resorbable wound dressing and as haemostatic agent.

Reviewer I: Is regenerated cellulose hydrogel nonimmunogenic in the human body?

Authors: The present authors have not studied immunogenicity of this particular type of cellulose, although several related investigations are indicated in the introduction. Depending on their composition, cellulose and its derivatives can elicit only a mild immunologic response after implantation. Some works related to blood contact applications have described cellulose as a polymer eliciting a low immune response (low phagocytosis by macrophages and low interleukin-1 release), and inducing a comparatively higher activation of the complement system.

J. de Bruijn: Can the authors speculate on the mechanism of mineralised deposit formation after already 3 days of cell culture? This can obviously not be de novo bone formation. Have the authors evaluated whether conditioned medium from control HBMSC cultures can also result in the apatitic layer formation when added to the regenerated cellulose hydrogels (in the absence of cells)?

Authors: Concerning the mechanism of mineralized deposit formation, we do not want to speculate at this point, but surely the whole phenomenon cannot be regarded as de novo bone formation. As stated in this manuscript, mineralization was not expected, and hence this control with culture medium without cells was not included in the experimental design. The referee is right in the sense that it is not possible to be sure that this mineralization is a result of the cultured HBMSC, or if only the medium contributed to this phenomenon. This aspect was added to the discussion and should be adequately clarified in future studies.

R. Oreffo: Given the lack of biodegradability of cellulose and requirement of functionalisation, could the authors indicate an orthopaedic application envisaged in the first instance?

Authors: In the first instance, it was envisaged to take advantage of its good mechanical properties and hydroexpansivity, coupled with biocompatibility, as a sealing material for the femoral component in hip prostheses, in place of the acrylic cement, as well as a dyaphyseal obturator. It could also be used as a bone filler in non load-bearing applications.
H. Plenk: Could the authors discuss SBF (simulated body fluid) experiments which showed that a mineralized layer is deposited on a variety of so-called "bioactive" but also "bioinert"materials without the presence of cells?

Authors: Mineralization in SBF has been widely investigated using several materials, as a means to ascertain their bioactivity. Studies in SBF were also carried out using these same cellulose materials and showed that no mineralization occurred in SBF, as indicated in the discussion. The composition of SBF and of the cell culture medium are clearly distinct, and thus no comparisons were attempted. The presence of cells further makes the present study undoubtedly divergent from studies in SBF.

H. Plenk: Were the authors aware of the studies by Kristen et al. (1977, 1978), and later by the people in Leiden ( $\mathrm{Li}$ et al., 1997a,b) on bone reactions to wood, and that mineralization occurs naturally in several species of wood? Authors: We are well aware of those studies and they are thoroughly discussed in our previous papers concerning mineralization studies of cellulose in SBF (references are provided in the introduction). However, as discussed in the previous item, such studies seem clearly different from in vitro studies where cells are present.

H. Plenk: While in the studies of Kristen et al. (1977, 1979) direct bone contacts to wood surfaces could be shown, no direct bone contact, but only a foreign body response was observed at the cellulose interfaces in your referenced study of Gross et al. (1992). Thus, the Gross et al. (1992) cellulose material, as well as the PLA-PGA materials, are not "osteoconductive" in my understanding. Could you comment on that?

Authors: You are right that the study from Gross et al. (1992) is incomplete, but further evidence of osteoconduction on cellulose is provided in the paper by Chauveaux et al. (1990) (text reference).

H. Plenk: When you observed this mineral deposition underneath the HBMS cells, why did they then not produce the bone nodules as in similar cell culture studies? Consequently, can you speculate from your results, if direct bone apposition would occur in vitro and in vivo?

Authors: The present study is focused on the analysis of the mineral layer formed between proliferating cells and the material surface. No differentiation studies were performed, although we are currently carrying out such studies using oxidized regenerated cellulose. However, from the present studies, it can speculated that the used materials, pre-colonized with cells, could promote direct bone apposition.

\section{Additional References}

Kristen H, Bosch P, Bednar H, Plenk H Jr (1977) Vertraeglichkeitsuntersuchungen von Holz im Knochengewebe (Biocompatibility of wood in bone tissue) Arch Orthop Unfallchir 89: 1-14.

Kristen H, Bosch P, Bednar H, Plenk H Jr (1979) The 
effects of dynamic loading on intracalcaneal wood implants and on the tissues surrounding them. Arch Orthop Trauma Surg. 93: 287-292

Li SH, Liu Q, de Wijn J, Zhou BL, de Groot K (1997a) Calcium phosphate formation induced on silica in bamboo.
J Mater Sci Mater Med 8: 427-433.

Li SH, Liu Q, de Wijn JR, Zhou BL, de Groot K (1997b) In vitro calcium phosphate formation on a natural composite material, bamboo. Biomaterials 18: 389-395 